\title{
Europeanisation at work in the Western Balkans and the Black Sea Region: Pan-European Voting in the United Nations General Assembly?
}

\author{
Florent Marciacq \\ Associate Researcher \\ University of Luxembourg, European Governance Programme \\ University of Vienna, Institute for Political Sciences \\ research@marciacq.org
}

\begin{abstract}
:
Is there an all-European way of voting in the United Nations General Assembly (UNGA), which transcends the borders of the European Union (EU) and affects, though differentially, the foreign policy of European non-EU states? To answer this question, this paper enquires into the voting behaviour in the UNGA of twelve non-EU states from the Western Balkans and the Black Sea region between 1993 and 2010. It assesses the voting distance of these non-EU states vis-à-vis EU positions, which it models either by proxy (using Luxembourg) or by unanimity. The paper finds that the multilateral diplomacy of most non-EU states has become distinctively convergent with EU preferences. It nevertheless observes notable cross-national variations, which it cannot trace back to differences in non-EU states' institutional distance to the EU. While acknowledging the role of compliance mechanisms, the paper suggests that other mechanisms (e.g. simple and social learning) may be at work.
\end{abstract}

Keywords: Europeanisation, foreign policy, voting behaviour, Western Balkans, Black Sea region 


\section{Introduction}

With the consolidation of the EU's political, legal and institutional structures, the issues raised by Europeanisation research have become more salient than ever. These issues, which were once only pertaining to adaptational change in core EU member states, have fuelled a growing research agenda (for an overview, see Graziano and Vink 2007). This paper intends to make a reflexive contribution to Europeanisation research in a geopolitical field that lies at the crux of two under-researched inquiries. Geographically, first, it explores Europeanisation in non-EU Europe, and more specifically in the Western Balkans and the Black Sea region, i.e. in states with differentiated -if any-perspectives of EU membership. Sectorally, then, the paper focuses on the Europeanisation of national foreign policies, and more specifically, on states' multilateral diplomacy in the United Nations General Assembly (UNGA). This twofold focus points at the necessity to broaden the ontological foundations upon which Europeanisation is being researched, whilst delineating more precisely the phenomenological traits of the inquiry. In substance, it contends that Europeanisation, phenomenologically, ensues through foreign policy convergence; spatially, that it extends beyond EU institutional borders; and aetiologically, that it is not limited to domestic responses to the EU's conditionality regimes.

The paper starts by discussing some conceptual and theoretical aspects of Europeanisation research, and pointing three challenges: first, how to measure Europeanisation in foreign policy, considering the little depth the concept usually displays? Second, how to conceive of Europeanisation in non-EU Europe, considering the prevalence of EU-centric models? Third, how to explain the Europeanisation of nonEU states' diplomacy in the UNGA, considering the weakness of the EU's CFSP acquis? The paper then researches empirically the voting behaviour of twelve non-EU states in the UNGA between 1993 and 2010. After evidencing differential patterns of foreign policy convergence, the paper assesses whether these differences can be traced back to notable differences in non-EU states' institutional distance to the EU. In conclusion, the paper acknowledges the relative effectiveness of EU foreign policy external coordination mechanisms, whilst evoking the possible role of social learning, simple learning and emulation in explaining Europeanisation.

\section{2. (Re)visiting Europeanisation}

\subsection{Europeanisation and foreign policy (convergence)}

How relevant is it to study Europeanisation in foreign policy matters? Foreign policy, which quintessentially, is about the external projection of domestic preferences that are “explicitly political or security related” (Smith 2003, 2), has long been associated with, and sacralised as, high politics. Traditionally seen as the preserve of Westphalian states, it then does not stand out as an obvious candidate in Europeanisation research. This is all the more logical considering the weakness of the acquis communautaire in CFSP matters, the implicit measure of supranationalism underlying many definitions of Europeanisation, 
and the fact that the EU, despite its hybrid nature, still heavily relies on its member states in foreign policy matters. These reserves, however, are no longer grounded, if one admits that the pursuit of foreign policy is not the idiosyncratic attribute of the state. Once limited to high politics, foreign policy has now come to embrace political objectives that are not directly related to states' existential conditions, but respond to environmental, human and socio-economic security concerns. With the opening-up of this "new security" agenda, the conduct, and the analysis, of foreign policy have changed. They are, in particular, more open to institutionalist forces, which an increasing number of organisational structures still nurture, especially in Europe. With the growing competencies conferred upon the EU in "lower spheres" of security policy, new vistas have been opened for Europeanisation research.

Europeanisation researchers, however, often remain reluctant to investigate what Europeanisation entails in phenomenological, rather than processual terms, throughout Europe (but see Marciacq 2010). This may explain why quantitative studies are scarcely used in Europeanisation research. Often, researchers assume that Europeanisation has no proper phenomenological manifestation of its own (other than "change"), which they could generalise as definitional trait. Their conclusions on the nature, scope and pace of Europeanisation typically remain specific to their study. This remains, arguably, a major flaw of Europeanisation research, because, as Sartori put it, "we cannot measure unless we first know what it is that we measure. Nor can the degrees of something tell us what a thing is" (1970, 61). A brief outlook of the specialised literature, however, shows that Europeanisation, in its most visible manifestation, affects foreign policy outputs by inducing a certain level of policy convergence (Marciacq 2010, 6-7). Policy convergence, understood as the "growing similarity of policies over time" (Holzinger and Knill 2005, 776), does not mean identity. It may for instance accommodate an "empirically observable differential impact” (Börzel and Risse 2000, 1), and even "considerable variability" (Radaelli 2003, 33), so that some authors, referring to the Europeanisation phenomenon, have preferably spoken of "clustered convergence" (Börzel and Risse 2000), or "convergence towards moderate diversity" (Falkner 2000). This paper accordingly operationalises this set of definitions by referring to Europeanisation in terms of voting similarity between EU and non-EU states, and more specifically, in terms of decreasing voting distances between non-EU states and EU modelled positions.

\subsection{Europeanisation in non-EU Europe}

Europeanisation research, as the "natural child of EU integration", has long focused on EU member states alone (Marciacq 2012). This is because the concept of Europeanisation, in many studies, is co-defined by EU integration. Conceptualised as the domestic impact of EU integration/membership, Europeanisation, often exhibits a conceptual domain that is delineated by the extent to which the EU has widened in territory and deepened in competency, and a geography that is ineluctably confined to that of the EU. This conceptual interweaving tends to neglect the spatial domain that exists between Europe 
and the EU -a "non-EU Europe" that Europeanisation research has no reason to discard (Marciacq 2012).

Fortunately enough, some students of Europeanisation recently stepped into the breach. They adopt a European governance, rather than EU integration approach to institutional change. Their work scrutinises the "external dimension of Europeanisation" in European states with no EU immediate accession perspective, or EU neighbouring spaces that have been targeted by European foreign policy actions (e.g. Lavenex and Ucarer 2004; Schimmelfennig 2009; Börzel 2010; Lavenex 2004; Lavenex et al. 2009). These studies cease to treat Europeanisation as the outgrowth of a sui generis phenomenon intrinsically linked to EU integration. They successfully show that the phenomenon, closely linked with new modes of European governance, spreads externally, across EU boundaries. The following paper, venturing in this debate, adopts such conceptual approach to Europeanisation.

To many researchers, however, it remains unclear how Europeanisation flows outwards, into non-EU Europe, and what forces drive this process. Some have argued that EU preferences are diffused externally, in concentric circles of external governance, through the outwards extension of the EU's rule-based authority. These circles differ from one another according to the legal-institutional relationship the EU has developed with nonEU states. Lavenex \& Ucarer (2004, 423), for instance, distinguish between close association (e.g. Switzerland), accession association (e.g. Croatia), pre-accession association (e.g. Serbia), neighbourhood association (e.g. Ukraine) and loose association (e.g. ACP countries) circles. Accession association supposes that the relationship between the EU and its partner is denser, in legal-institutional terms, than loose association. This approach is premised on the ontological prevalence of contractual forces (e.g. legal, political obligations) responsible for inducing domestic change, generally through compliance and conditionality. It assumes that the farther the institutional distance from the EU, the weaker Europeanisation in non-EU Europe.

Another way of conceiving outwards Europeanisation is premised on a more idealistic, sociological approach of interactions. Rather than focusing on the legal-institutional dimension of EU/non-EU relationships, this approach underlines that borders today, have become ontologically permeable or "fuzzy" (Christiansen et al. 2000). This is most obvious in the EU's "near abroad" (Christiansen et al. 2000), or "wider-Europe" (Lavenex 2004), i.e. in those "intermediate spaces between the inside and the outside of the Union" (Christiansen et al. 2000, 411ff.). Therein, speaking of clearly identifiable, concentric circles of external governance is at best illusory. Europeanisation does not flow structurally from a reified EU centre towards institutionally differentiated circles of non-EU Europes. It affects states' policy structures through the construction and reproduction of ideational constructs, which endogenously command policy changes. This may in particular involve thick, norm-laden interactions (conducive to social learning) or, more agency-based processes (e.g. emulative and simple learning), which very much depend on the non-EU states' domestic specifics. 


\section{Measuring Europeanisation in the UNGA}

Europeanisation research has not been very prolific in the specific field of diplomacy (but see Blair 2004; Marciacq 2011). Studies surveying states' voting behaviour at the UNGA were generally conducted so as to make a contribution to European foreign policy research, and barely addressed Europeanisation issues. Scholars have for instance studied cases of "solidarity” (e.g. Foot 1979), “convergence” (Beauguitte 2009), alignment (Powers 1980), Kohärenz (Stadler 1993), and, above all, “cohesion” (Hosli et al. 2010; Kissack 2007; Luif 2003; Hurwitz 1975) in the UNGA. Other studies have also focused on EU member states' foreign policy coordination in the UNGA, but here again, with no reference to Europeanisation (see most notably Rasch 2008; Laatikainen and Smith 2006).

\subsection{Voting in the UN General Assembly}

The choice of the United Nations General Assembly (UNGA) as a source of data for this study is motivated by various factors. First, the UNGA is "arguably the most important forum for the discussion of global politics” (Peterson 2006, i). Therein, all UN member states are able to express their positions on a wide variety of foreign policy issues, most notably by casting votes. Their votes are a good depiction of the expression of their interests and preferences in world politics (Luif 2003, 13). The themes covered by UNGA resolutions are delineated by article 13 of the UN Charter, and they are reflected by the interests of the six UNGA Main Committees, i.e. disarmament and international security issues; political issues and decolonisation; economic and financial issues; social, humanitarian and cultural issues; administrative and budgetary issues and legal issues (Rule 98, United Nations 1984). Second, this multilateral forum, at the core of the UN system, is of utmost importance to the EU. The EU is indeed committed to "support" the United Nations in strengthening "an international order based on effective multilateralism” (European Security Strategy, 2003, III).

Resolutions at the UNGA are passed on a one-country, one-vote basis (Rule 82, United Nations 1984) in accordance with the UN "sovereign equality principle" (Article 2 (1) of the Charter of the United Nations). Although the voting rule, defined in the UN Charter and in the UNGA Rules of Procedure, is majoritarian, in practice, decision by consensus (i.e. with no vote) prevails in no less than $70 \%$ of the draft resolutions (Peterson 2006, 74; see also Luif 2003, 22). Rule 87b of the UNGA Rules of Procedure, however, states that "any representative may request a recorded vote", in which case the roll-call voting procedure shall apply. Only the most controversial and politicised resolutions follow this path. Recorded votes are registered by the UN Bibliographic Information System (UNBIS) and are readily available for public consultation.

Only the member states of the United Nations are entitled to casting votes in the UNGA. As the EU is not recognised as a full member of the UN, it cannot vote in the UNGA. Just as the OSCE and the Council of Europe, the EU, to date, remains an observer in the UNGA (although lobbying is currently deployed in the UNGA to enhance EU's rights 
therein). Determining the foreign policy position of the EU on a given set of UNGA resolutions and, on the basis of this pivotal position, assessing the distance that separates the EU from non-EU states may therefore prove highly problematic. This obstacle may be circumvented by modelling the positions of the EU either by proxy, or by unanimity (see below).

\subsection{Data and method}

The dataset that will be used in this study is composed of the recorded foreign policy positions of chosen states as they were expressed through roll-call votes in the UNGA. The temporal scope of the research spans from the establishment of the EU by the Maastricht Treaty in 1993 ( $52^{\text {nd }}$ Plenary Session of the UNGA) to the full entry into force of the Lisbon Treaty in 2010 ( $65^{\text {th }}$ Plenary Session of the UNGA). The geographical scope of the research encompasses EU member states (EU 12,15,25,27) and twelve states from the Western Balkans and Black Sea region, which are associated to the EU as of 2010 (i.e. Croatia, Macedonia, Montenegro, Turkey, Albania, Serbia, BosniaHerzegovina, Ukraine, Moldova, Georgia, Armenia, Azerbaijan). The data are both collected from a research database compiling UN records until 2007 (Voeten 2008), and retrieved manually from the UNBIS Website for subsequent years (UN Bibliographic Information System).

The original data, as recorded in the UNGA, may take five different values: [yes], [no], [abstain], [absent] and [not a member]. In this paper, the data are re-coded. First, [not a member] values are discarded from the dataset as they do not carry substantive information of states' foreign policy choices (e.g. Serbia 1997-1999, Montenegro 19932005). [Abstain] and [absent], by contrast, are considered just similarly as [yes] and [no], i.e. as substantive positions -except when [absence] is systematic, i.e. is repeated more than ten times in a raw (e.g. Serbia 1993-1997, Albania 07/2000, Bosnia 02/1999). When [absence] is systematic, then the records are discarded as non-data. Otherwise, they are treated as [abstain]. This re-coding is consistent with other studies (e.g. Luif 2003; Hurwitz 1975). It considers that states may choose to avoid confrontational dissent by being selectively absent or abstaining. Though different in behaviour, both non-voting options may be considered as expressing attitudinal preferences. In deciding whether this non-voting option shall be given the same substantive weight as [yes] and [no], this study follows Luif (2003) and Hurwitz (1975) contra Hix, Noury and Roland (2005). It treats [abstain] and [absent] as "partial agreement” (Hurwitz 1975, 229). The data, accordingly, are re-coded as ordinal variables, as follows: [yes] $=1$, [no] $=0$ and [abstain] $=0.5$.

The degree of policy convergence is measured by computing dyadically the voting distance that separates the position of two foreign policy actors (one EU, one non-EU) on a given resolution $\mathrm{x}$. As the variable takes numerical values, the voting distance (VDI) between two partners over a predefined period of time $t$ can be aggregated arithmetically into: 


$$
V D I_{t}=\frac{\sum_{t}\left|A_{x}-B_{x}\right|}{n}
$$

whereby $\left|A_{x}-B_{x}\right|$ is the voting distance on resolution $\mathrm{x}$ between $\mathrm{A}$ and $\mathrm{B}$, and $\mathrm{n}$ represents the total number of resolutions for which both parties to the dyad expressed a position. If for a given resolution $\mathrm{x}$, the voting position of $\mathrm{A}$ is strictly identical to the voting position of $\mathrm{B}$, then, $\mathrm{VDI}_{\mathrm{x}}$ is 0 .

The voting position of the actor "EU" is modelled in two different ways. First, it is modelled by proxy, using Luxembourg's voting behaviour as pivotal point of reference. Luxembourg, being one of "most Community-minded of all the member states" (Foot 1979, 357), typically votes in the UNGA as the majority of the member states in all the resolutions submitted to vote, and with minimal voting deviation from the EU's median position (see Table 1). This voting behaviour contrasts for instance with the relatively peculiar voting behaviour of France and the UK (see Beauguitte 2009; Foot 1979, 352ff.; Luif 2003; Hurwitz 1975).

Table 1: Selecting the best EU proxy among EU member states

\begin{tabular}{|c|c|c|}
\hline \multirow{3}{*}{ Best proxy } & \multicolumn{2}{|c|}{$\begin{array}{l}\text { Total voting distance (VDI) } \\
\text { from EU (15) median position 1993-2010 }\end{array}$} \\
\hline & LUX & 12 \\
\hline & DEN & 15.5 \\
\hline \multirow{13}{*}{$\begin{array}{c}\downarrow \\
\text { Worst proxy }\end{array}$} & NTH & 16.5 \\
\hline & ITA & 18 \\
\hline & BEL & 19 \\
\hline & GER & 21 \\
\hline & FIN & 21.5 \\
\hline & POR & 22 \\
\hline & SPN & 33.5 \\
\hline & AUS & 40.5 \\
\hline & SWD & 47.5 \\
\hline & GRC & 58.5 \\
\hline & IRL & 56.5 \\
\hline & FRN & 108.5 \\
\hline & UKG & 132 \\
\hline
\end{tabular}

Source: own calculations based on UNBIS and Voeten 2008 databases

The positions of the EU will secondly be modelled by identifying those resolutions where the member states of the EU $(12,15,25,27)$ voted unanimously (see Beauguitte 2009; Luif 2003). This represents 74\% of the resolutions between 1993 and 2010 -a shrinking percentage though (see Figure 1). In the absence of consensus, the calculations cannot be performed, as no European position is said to have emerged. In praxis, this means that EU consensus positions can only be compared to non-EU's after EU member states have 
successfully coordinated their foreign policy, generally in New York, through the internal coordination meetings at the expert and ambassadorial levels.

Figure 1: EU member states (EU MS) voting cohesion at the UNGA

$\square$ EU unanimity votes $\quad \square$ no unanimity among EU MS

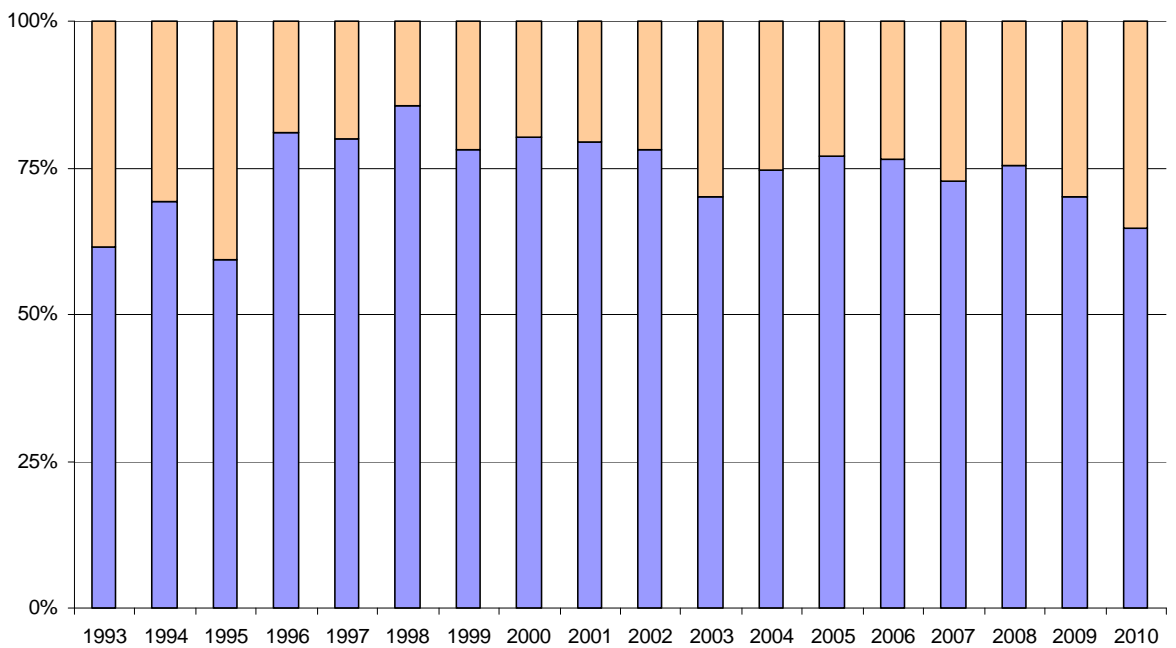

Source: own calculations based on UNBIS and Voeten 2008 databases

Based on this twofold modelling, the voting distance of the twelve non-EU states vis-àvis the EU have been calculated by comparing systematically non-EU states' positions to the EU's proxy and unanimity positions (see Table 2 and Table 3).

\section{Table 2: Voting distance from EU proxy positions (Luxembourg)}

\begin{tabular}{|c|c|c|c|c|c|c|c|c|c|c|c|c|c|c|c|}
\hline & $\begin{array}{l}\text { number of } \\
\text { resolutions }\end{array}$ & SLV & CRO & MAC & MNG & TUR & ALB & SRB & BOS & UKR & MDA & GEO & ARM & AZE & RUS \\
\hline 1993 & 64 & $6 \%$ & $16 \%$ & $18 \%$ & & $15 \%$ & $16 \%$ & & $28 \%$ & $22 \%$ & $7 \%$ & $16 \%$ & $16 \%$ & $25 \%$ & $15 \%$ \\
\hline 1994 & 68 & $6 \%$ & $12 \%$ & $8 \%$ & & $12 \%$ & $7 \%$ & & $21 \%$ & $11 \%$ & $8 \%$ & $10 \%$ & $15 \%$ & $21 \%$ & $19 \%$ \\
\hline 1995 & 81 & $7 \%$ & $8 \%$ & $9 \%$ & & $12 \%$ & $9 \%$ & & $16 \%$ & $12 \%$ & $9 \%$ & $28 \%$ & $12 \%$ & $20 \%$ & $17 \%$ \\
\hline 1996 & 74 & $3 \%$ & $8 \%$ & $7 \%$ & & $14 \%$ & $6 \%$ & & $18 \%$ & $15 \%$ & $11 \%$ & $15 \%$ & $16 \%$ & $22 \%$ & $18 \%$ \\
\hline 1997 & 70 & $3 \%$ & $7 \%$ & $10 \%$ & & $15 \%$ & $7 \%$ & & & $14 \%$ & $9 \%$ & $13 \%$ & $10 \%$ & $22 \%$ & $20 \%$ \\
\hline 1998 & 61 & $2 \%$ & $3 \%$ & $6 \%$ & & $11 \%$ & $2 \%$ & & & $13 \%$ & $4 \%$ & $14 \%$ & $14 \%$ & $20 \%$ & $18 \%$ \\
\hline 1999 & 68 & $2 \%$ & $7 \%$ & $7 \%$ & & $10 \%$ & $11 \%$ & & $12 \%$ & $14 \%$ & $4 \%$ & $10 \%$ & $17 \%$ & $21 \%$ & $19 \%$ \\
\hline 2000 & 66 & $2 \%$ & $5 \%$ & $3 \%$ & & $10 \%$ & $10 \%$ & $0 \%$ & $15 \%$ & $13 \%$ & $6 \%$ & $8 \%$ & $20 \%$ & $23 \%$ & $23 \%$ \\
\hline 2001 & 68 & $1 \%$ & $5 \%$ & $4 \%$ & & $12 \%$ & $5 \%$ & $4 \%$ & $7 \%$ & $13 \%$ & $7 \%$ & $12 \%$ & $19 \%$ & $27 \%$ & $23 \%$ \\
\hline 2002 & 72 & $1 \%$ & $2 \%$ & $3 \%$ & & $10 \%$ & $6 \%$ & $3 \%$ & $7 \%$ & $13 \%$ & $6 \%$ & $6 \%$ & $19 \%$ & $25 \%$ & $19 \%$ \\
\hline 2003 & 77 & $4 \%$ & $3 \%$ & $5 \%$ & & $12 \%$ & $7 \%$ & $5 \%$ & $6 \%$ & $16 \%$ & $10 \%$ & $14 \%$ & $19 \%$ & $32 \%$ & $22 \%$ \\
\hline 2004 & 69 & $2 \%$ & $2 \%$ & $4 \%$ & & $7 \%$ & $10 \%$ & $3 \%$ & $4 \%$ & $12 \%$ & $5 \%$ & $7 \%$ & $18 \%$ & $26 \%$ & $25 \%$ \\
\hline 2005 & 74 & $1 \%$ & $1 \%$ & $3 \%$ & & $7 \%$ & $14 \%$ & $1 \%$ & $5 \%$ & $7 \%$ & $5 \%$ & $3 \%$ & $18 \%$ & $24 \%$ & $22 \%$ \\
\hline 2006 & 84 & $1 \%$ & $1 \%$ & $1 \%$ & $2 \%$ & $7 \%$ & $2 \%$ & $1 \%$ & $3 \%$ & $1 \%$ & $5 \%$ & $2 \%$ & $18 \%$ & $24 \%$ & $25 \%$ \\
\hline 2007 & 77 & $1 \%$ & $1 \%$ & $1 \%$ & $3 \%$ & $8 \%$ & $8 \%$ & $4 \%$ & $5 \%$ & $3 \%$ & $1 \%$ & $3 \%$ & $19 \%$ & $29 \%$ & $24 \%$ \\
\hline 2008 & 76 & $0 \%$ & $0 \%$ & $0 \%$ & $2 \%$ & $9 \%$ & $3 \%$ & $10 \%$ & $1 \%$ & $3 \%$ & $1 \%$ & $3 \%$ & $18 \%$ & $27 \%$ & $27 \%$ \\
\hline 2009 & 67 & $1 \%$ & $1 \%$ & $2 \%$ & $1 \%$ & $13 \%$ & $3 \%$ & $12 \%$ & $5 \%$ & $1 \%$ & $1 \%$ & $1 \%$ & $22 \%$ & $29 \%$ & $28 \%$ \\
\hline 2010 & 71 & $4 \%$ & $6 \%$ & $7 \%$ & $2 \%$ & $12 \%$ & $4 \%$ & $17 \%$ & $6 \%$ & $4 \%$ & $4 \%$ & $8 \%$ & $22 \%$ & $26 \%$ & $29 \%$ \\
\hline
\end{tabular}

Source: own calculations based on UNBIS and Voeten 2008 databases

Table 3: Voting distance from EU unanimous positions 


\begin{tabular}{|c|c|c|c|c|c|c|c|c|c|c|c|c|c|c|c|}
\hline & $\begin{array}{l}\text { number of } \\
\text { EU positions }\end{array}$ & SLV & CRO & MAC & MNG & TUR & ALB & SRB & BOS & UKR & MDA & GEO & ARM & AZE & RUS \\
\hline 1993 & 38 & $6 \%$ & $18 \%$ & $15 \%$ & & $11 \%$ & $14 \%$ & & $30 \%$ & $13 \%$ & $6 \%$ & $16 \%$ & $11 \%$ & $20 \%$ & $13 \%$ \\
\hline 1994 & 44 & $3 \%$ & $9 \%$ & $6 \%$ & & $12 \%$ & $6 \%$ & & $18 \%$ & $7 \%$ & $5 \%$ & $9 \%$ & $7 \%$ & $17 \%$ & $17 \%$ \\
\hline 1995 & 46 & $3 \%$ & $6 \%$ & $3 \%$ & & $8 \%$ & $5 \%$ & & $14 \%$ & $9 \%$ & $6 \%$ & $8 \%$ & $7 \%$ & $20 \%$ & $14 \%$ \\
\hline 1996 & 56 & $2 \%$ & $4 \%$ & $3 \%$ & & $15 \%$ & $4 \%$ & & $15 \%$ & $10 \%$ & $8 \%$ & $13 \%$ & $13 \%$ & $18 \%$ & $14 \%$ \\
\hline 1997 & 56 & $1 \%$ & $3 \%$ & $4 \%$ & & $13 \%$ & $4 \%$ & & & $11 \%$ & $6 \%$ & $11 \%$ & $8 \%$ & $17 \%$ & $17 \%$ \\
\hline 1998 & 52 & $0 \%$ & $1 \%$ & $4 \%$ & & $10 \%$ & $1 \%$ & & & $11 \%$ & $2 \%$ & $14 \%$ & $13 \%$ & $19 \%$ & $16 \%$ \\
\hline 1999 & 53 & $1 \%$ & $4 \%$ & $5 \%$ & & $9 \%$ & $12 \%$ & & $13 \%$ & $11 \%$ & $3 \%$ & $9 \%$ & $14 \%$ & $20 \%$ & $14 \%$ \\
\hline 2000 & 51 & $0 \%$ & $3 \%$ & $1 \%$ & & $11 \%$ & $9 \%$ & $0 \%$ & $16 \%$ & $9 \%$ & $3 \%$ & $7 \%$ & $18 \%$ & $22 \%$ & $20 \%$ \\
\hline 2001 & 53 & $1 \%$ & $3 \%$ & $4 \%$ & & $13 \%$ & $3 \%$ & $2 \%$ & $6 \%$ & $10 \%$ & $5 \%$ & $10 \%$ & $16 \%$ & $28 \%$ & $20 \%$ \\
\hline 2002 & 51 & $0 \%$ & $1 \%$ & $1 \%$ & & $9 \%$ & $5 \%$ & $0 \%$ & $4 \%$ & $9 \%$ & $4 \%$ & $3 \%$ & $18 \%$ & $25 \%$ & $19 \%$ \\
\hline 2003 & 53 & $0 \%$ & $0 \%$ & $2 \%$ & & $11 \%$ & $5 \%$ & $1 \%$ & $4 \%$ & $9 \%$ & $6 \%$ & $10 \%$ & $16 \%$ & $27 \%$ & $17 \%$ \\
\hline 2004 & 48 & $0 \%$ & $0 \%$ & $1 \%$ & & $8 \%$ & $11 \%$ & $0 \%$ & $0 \%$ & $12 \%$ & $4 \%$ & $5 \%$ & $19 \%$ & $28 \%$ & $27 \%$ \\
\hline 2005 & 56 & $0 \%$ & $0 \%$ & $1 \%$ & & $7 \%$ & $12 \%$ & $0 \%$ & $5 \%$ & $5 \%$ & $5 \%$ & $3 \%$ & $17 \%$ & $24 \%$ & $23 \%$ \\
\hline 2006 & 62 & $0 \%$ & $0 \%$ & $1 \%$ & $3 \%$ & $6 \%$ & $2 \%$ & $0 \%$ & $4 \%$ & $0 \%$ & $5 \%$ & $1 \%$ & $16 \%$ & $25 \%$ & $24 \%$ \\
\hline 2007 & 48 & $0 \%$ & $0 \%$ & $0 \%$ & $3 \%$ & $9 \%$ & $9 \%$ & $4 \%$ & $4 \%$ & $3 \%$ & $1 \%$ & $4 \%$ & $21 \%$ & $32 \%$ & $29 \%$ \\
\hline 2008 & 57 & $1 \%$ & $0 \%$ & $1 \%$ & $0 \%$ & $9 \%$ & $2 \%$ & $9 \%$ & $2 \%$ & $3 \%$ & $0 \%$ & $3 \%$ & $17 \%$ & $25 \%$ & $26 \%$ \\
\hline 2009 & 45 & $0 \%$ & $1 \%$ & $1 \%$ & $1 \%$ & $11 \%$ & $1 \%$ & $10 \%$ & $2 \%$ & $0 \%$ & $0 \%$ & $1 \%$ & $22 \%$ & $32 \%$ & $31 \%$ \\
\hline 2010 & 42 & $0 \%$ & $1 \%$ & $0 \%$ & $0 \%$ & $10 \%$ & $1 \%$ & $8 \%$ & $5 \%$ & $0 \%$ & $0 \%$ & $3 \%$ & $21 \%$ & $29 \%$ & $27 \%$ \\
\hline
\end{tabular}

Source: own calculations based on UNBIS and Voeten 2008 databases

\section{How $\operatorname{close}(r)$ to the EU is non-EU states' voting behaviour?}

\subsection{Distant, non-convergent voting behaviour (Armenia and Azerbaijan)}

Over the past seventeen years, Armenia and Azerbaijan have not come closer the EU as regards their voting behaviour in the UNGA. Their voting behaviour has been characterised by rising voting distances, as shown by Figure 2. In addition to being divergent, Armenia and Azerbaijan's voting behaviour remains relatively distant from the EU's modelled positions in absolute terms. As it will be shown below, the voting distance between the EU and its Eastern and South-eastern partners has remained constantly lower than 15\% throughout the 1997-2010 period, except for Armenia and Azerbaijan, where it mostly remained over $15 \%$ for the former and $25 \%$ for the latter. Although Armenia and Azerbaijan's voting distances are lower on UNGA draft resolutions where the EU is unanimous, the two countries, overall, often tend to follow Russia. 
Figure 2: Divergent behaviour (increasing voting distance to the EU)

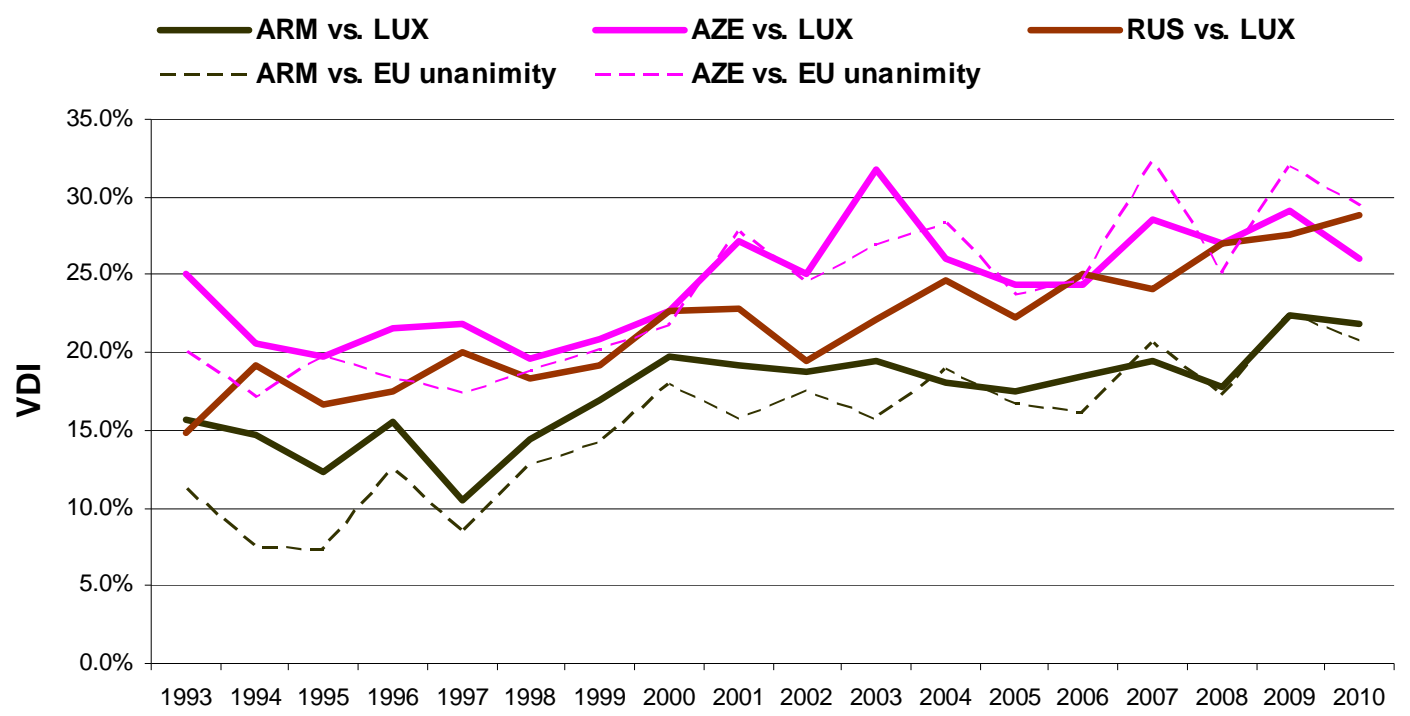

Source: own calculations based on UNBIS and Voeten 2008 databases

\subsection{Unsteady behaviour (Turkey, Albania and Serbia)}

The second group of countries identified here includes Turkey, Albania and Serbia. These countries' voting behaviour admits relatively high fluctuations with respect to their overall distance to EU positions, and little, if any, convergence over time. It is, here, necessary to distinguish between Turkey and Albania on the one side and Serbia on the other side. Turkey and Albania's voting behaviour in the UNGA is, overall, rather convergent with the EU, but not clearly so. Figure $\mathbf{3}$ shows that their voting distance index over the past seventeen years numbers several ups-and-downs with significant short-term variability. Despite their variability in voting convergence, both states remained relatively close to the EU. Their average voting distance between 1993 and 2010 was respectively $9.9 \%$ and $6.9 \%$, though Albania, on occasion, came much closer to the EU (e.g. 1.9\% in 1998). Serbia, by contrast, started its UN membership in 2000 (as Federal Republic of Yugoslavia) with extremely high levels of voting similarity. It behaved in a quasi-identical manner just as the EU between 2000 and 2006, and even more so, when the EU spoke with one voice. In 2000, 2002, 2003, 2004 and 2005, Serbia adopted all EU's unanimous positions with no exception. But in 2007, its voting behaviour suddenly became divergent, and in 2010, its voting distance for the first time exceeded 15\% (EU proxy). Characteristically high is finally the discrepancy between Serbia's voting distance to EU proxy and EU unanimity in 2010, which illustrates the strength of the EU's common voice, when it succeeds in being articulated. 
Figure 3: Inconclusive behaviour (fluctuating voting distance to the EU)

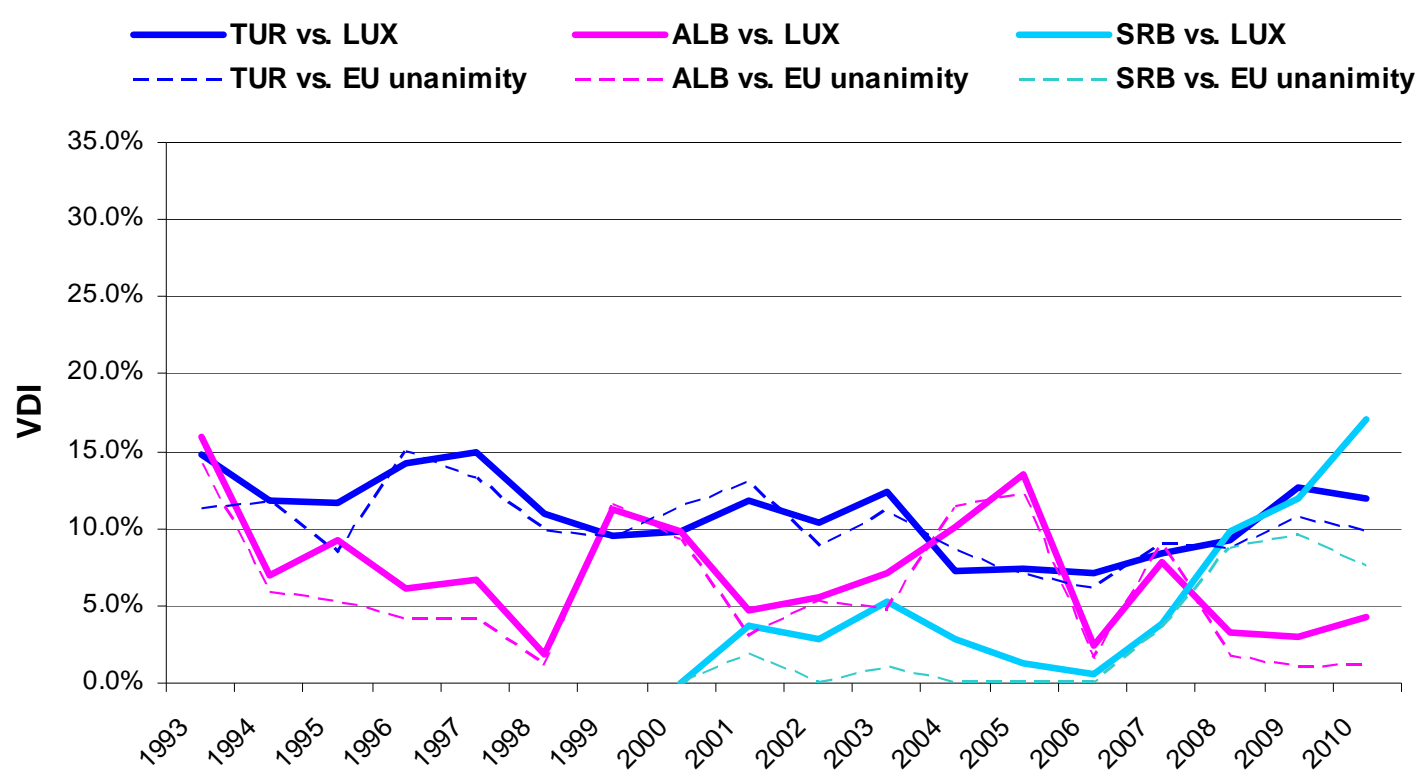

Source: own calculations based on UNBIS and Voeten 2008 databases

\subsection{Convergence towards EU identity}

The third group of countries under consideration here displays highly convergent patterns of voting behaviour, which tend towards perfect identity with EU's positions. Figure 4 illustrates this tendency, whereby states, starting with voting distance indexes ranging between 15.6\% (Croatia) and 28.1\% (Bosnia-Herzegovina) in 1993 (with the exception of Moldova at 7\%) ended up with a null or quasi-null voting distance index in 2008. This convergence has been remarkable for three reasons: first, it started at levels that were higher or roughly equal than the two other groups. Second, their voting behaviour aligned itself with the EU's following a gradual and relatively smooth pattern of convergence, although some acceleration in Ukraine, Georgia and Moldova's rapprochement with the EU is perceptible as of 2003. Finally, it can be stressed that the voting behaviour of these seven states has now come close to EU identity. In 2008, almost no dissent with EU unanimity positions has been recorded in their voting behaviour. With the recent decrease in the EU's voting cohesion (see Figure 1), however, these seven states did not maintain their quasi-null voting distance index in 2009 and 2010, although its level remains distinctively low. 
Figure 4: Highly convergent behaviour (decreasing voting distance to the EU)

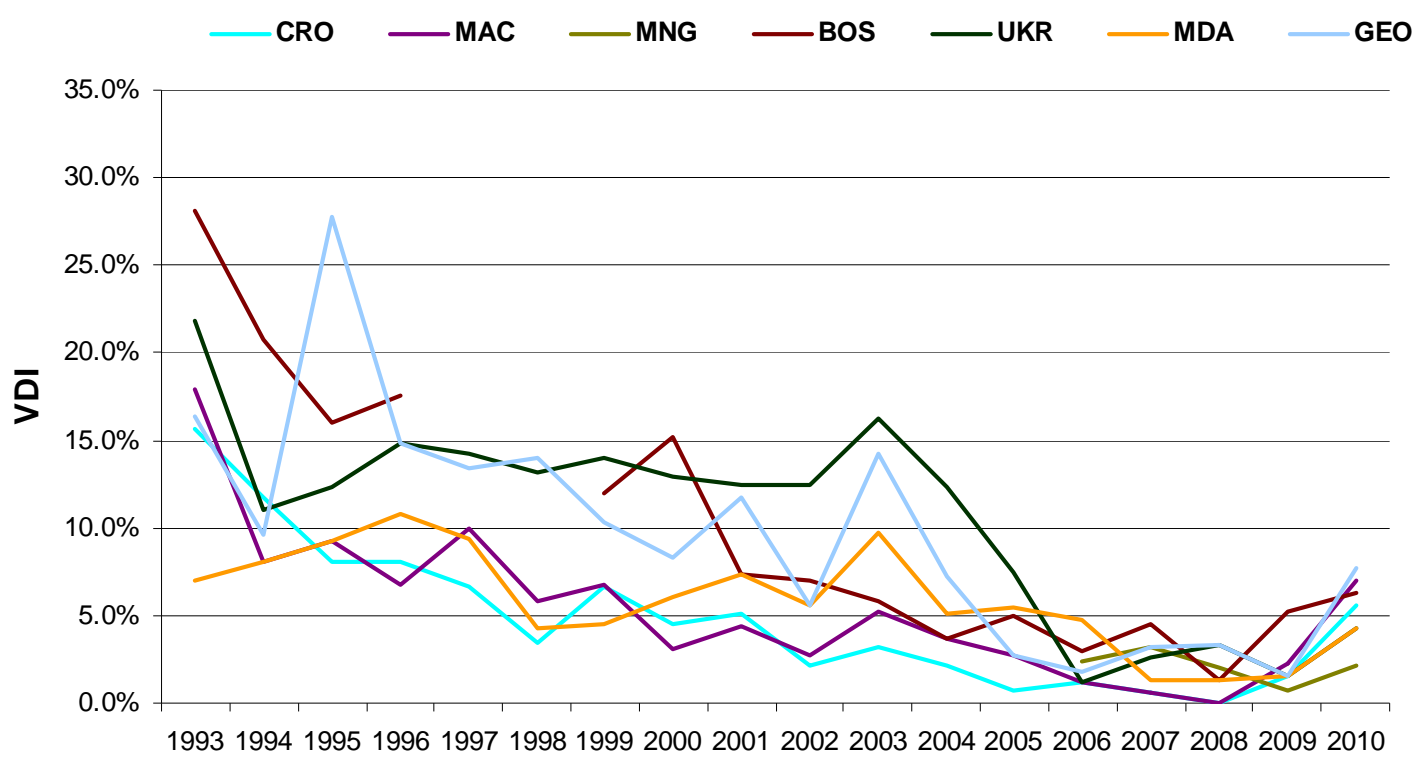

Source: own calculations based on UNBIS and Voeten 2008 databases

\section{Does institutional propinquity foster foreign policy convergence?}

Throughout the past two decades, the EU has developed extensive relations with all its Eastern partners. These relations have been institutionalised through a variety of legal and political frameworks, generally designed as part of regional cooperation/integration packages, e.g. Wider Europe (2003), European Neighbourhood Policy (2004), Black Sea Synergy (2008), Eastern Partnership (2008), Western Balkans Regional Approach (1997), and Stabilisation and Association process (2000). The institutional density of these regional packages considerably differs -in the sectoral scope of cooperation they cover, in the instruments and mechanisms they introduce, and in the European perspectives they offer. The Stabilisation and Association process (SAp), for instance includes dimensions of political cooperation and financial instruments that the Black Sea Synergy does not. Likewise, it offers European accession perspectives, which Associates to the European Neighbourhood Policy (ENP) cannot reckon as granted. These regional packages, which extend the authority of the EU beyond its actual borders, locate their signatories at different institutional distances from the EU. It is therefore legitimate to ask: how much does this institutional distance matter in the UNGA? To what extent does it explain the (emergence of different) patterns of change in EU partners' voting behaviour?

\subsection{The EU membership incentive}

It is doubtful that the institutional status conferred by the EU upon its Eastern partners suffices to explain voting convergence in the UNGA. Table 4 shows that the EU's partners from the Western Balkans and Black Sea region have not all been granted with 
explicit perspectives of EU accession. But neither their actual status, nor the underlying accession perspectives seem to act as a strongly correlative factor that can explain the differential patterns of voting convergence. For instance, whereas European perspectives have been promised to Western Balkan states during the Thessaloniki Summit in 2003, the EU has remained more elusive as for the prospects of Black Sea states. ENP action plans usually only state that "the EU takes note of [its ENP partners"] expressed European aspirations”. It could therefore be expected that ENP Associates should be less prone to voting alignment with EU positions than Western Balkan states, owing to their institutional distance to the EU. This seems indeed to be the case for Armenia and Azerbaijan, but not for Georgia and Moldova. These are part of the "high convergence" group, although their institutional ties to the EU remain as weak as those of the "nonconvergence" group. Besides, the heterogeneity of the "high convergence" group in terms of institutional distance makes this structural variable inconclusive. All in all, it is true that the promise of European perspectives certainly fosters voting alignment. None of EU prospective members belongs to the "non-convergence group". In that sense, it seems a sufficient condition for explaining convergence -but not a necessary one. 
Table 4: non-EU states' institutional distance to the EU

\begin{tabular}{|c|c|c|c|c|}
\hline & $\begin{array}{l}\text { Agreements } \\
\text { with the EU }\end{array}$ & $\begin{array}{c}\text { Accession } \\
\text { perspectives (2010) }\end{array}$ & \multicolumn{2}{|c|}{ Accession Status } \\
\hline \multicolumn{5}{|c|}{ Group 1: non-convergence } \\
\hline Armenia & $\begin{array}{l}\text { PCA }(1996,1999) \text {, } \\
\text { ENP-AP }(2006)\end{array}$ & not explicit & ENP Associate & \\
\hline Azerbaijan & $\begin{array}{l}\text { PCA }(1996,1999), \\
\text { ENP-AP }(2006)\end{array}$ & not explicit & ENP Associate & \\
\hline \multicolumn{5}{|c|}{ Group 2: unsteady convergence } \\
\hline Turkey & $\begin{array}{l}\text { AA (1963), AP } \\
\text { (2001) }\end{array}$ & yes but... & Negotiating $(99,05)$ & \\
\hline Albania & $\begin{array}{l}\text { SAA (2003, 2006, } \\
\text { 2009) }\end{array}$ & yes & Applicant (2009) & \\
\hline Serbia & SAA (2005, 2008, --) & yes & Applicant (2009) & \\
\hline \multicolumn{5}{|c|}{ Group 3: convergence towards identity } \\
\hline Croatia & $\begin{array}{l}\text { SAA (2000, 2001, } \\
\text { 2005) }\end{array}$ & yes & Negotiating $(04,05)$ & \\
\hline Macedonia & $\begin{array}{l}\text { SAA( 2000, 2001, } \\
\text { 2004) }\end{array}$ & yes & Candidate (2005) & \\
\hline Montenegro & $\begin{array}{l}\text { SAA (2005, 2007, } \\
\text { 2010) }\end{array}$ & yes & Candidate (2010) & \\
\hline Bosnia-Herz. & SAA $(2005,2008,--)$ & yes & SAp Associate & \\
\hline Ukraine & $\begin{array}{l}\text { PCA }(1994,1998), \\
\text { ENP-AP }(2005)\end{array}$ & no, but... & ENP Associate & \\
\hline Moldova & $\begin{array}{l}\text { PCA }(1994,1998), \\
\text { ENP-AP }(2005)\end{array}$ & not explicit & ENP Associate & \\
\hline Georgia & $\begin{array}{l}\text { PCA }(1996,1999), \\
\text { ENP-AP }(2006)\end{array}$ & not explicit & ENP Associate & \\
\hline \multicolumn{2}{|c|}{$\begin{array}{l}\text { SAA (yy,yy, yy) : Stabilisation \& } \\
\text { Association Agreement (negotiations } \\
\text { started, signed, entry into force) } \\
\text { AA (yy) : Association Agreement (signed) } \\
\text { AP (yy) : Accession Partnership (adopted) } \\
\text { PCA (yy,yy) : Partnership and Cooperation } \\
\text { Agreement (signed, entry into force) ; } \\
\text { ENP-AP (yy) : European Neighbourhood } \\
\text { Policy Action Plan (signed) }\end{array}$} & \multicolumn{3}{|c|}{ Negotiating (yy,yy) : (candidate status, start of negotiating) } \\
\hline
\end{tabular}

\subsection{CFSP obligations in the framework of EU/non-EU political dialogue}

The EU is often seen as a "rule-based polity" (Olsen 2007, chap. 8). And indeed, it has developed with its European non-EU partners a series of contractual relations, which extend the realm of its governance beyond its institutional borders. The most obvious illustration of this extended governance is the EU's conditionality regimes, developed with the EU's external partners in preparation of their institutional rapprochement with the EU. Amidst the plethora of rules codifying EU/non-EU relations, some pertain to foreign policy coordination in multilateral fora. These are usually enshrined in a relatively uniform wording as part of EU's political dialogue with European states (see Table 5 for the references). These rules convey two kinds of obligations: one is an obligation de moyens regarding foreign policy coordination in international organisations; the other is an obligation de résultat regarding foreign policy convergence. 
Table 5: Legal framework for EU/non-EU political dialogue in multilateral fora

\begin{tabular}{|c|c|c|c|}
\hline & $\begin{array}{c}\text { Obligation to } \\
\text { coordinate }\end{array}$ & $\begin{array}{c}\text { Obligation to } \\
\text { converge }\end{array}$ & Legal basis \\
\hline \multicolumn{4}{|c|}{ Group 1: divergent or loosely convergent } \\
\hline Armenia & 1999 & -- & $\begin{array}{l}\text { PCA (OJ L 239, 09/09/1999) } \\
\text { ENP-AP (doc. UE-AM 4553/06) }\end{array}$ \\
\hline Azerbaijan & 1999 & -- & $\begin{array}{l}\text { PCA (OJ L 246, 17/09/1999) } \\
\text { ENP-AP (doc. UE-AZ 4603/06 }\end{array}$ \\
\hline \multicolumn{4}{|c|}{ Group 2: unsteady convergence } \\
\hline Turkey & 1995 & 2005 & $\begin{array}{l}\text { Ass. Council Res. (doc. CE-TR 130/95) } \\
\text { Helsinki Summit Presidency Conclusions (99) } \\
\text { Negotiating framework }(3 / 10 / 2005,7)\end{array}$ \\
\hline Albania & 1992 & 1992 & $\begin{array}{l}\text { Joint Declaration (doc. 6166/92, Annex) } \\
\text { Thessalonica agenda (doc. 10369/03) } \\
\text { SAA (doc. 8164/06) }\end{array}$ \\
\hline Serbia & 2003 & 2003 & $\begin{array}{l}\text { Joint Declaration (OJ C 240, 07/10/2003) } \\
\text { Thessalonica agenda (doc. 10369/03) } \\
\text { SAA (doc. 16005/07) }\end{array}$ \\
\hline \multicolumn{4}{|c|}{ Group 3: convergent towards identity } \\
\hline Croatia & 2001 & 2001 & $\begin{array}{l}\text { Joint Declaration (13344/01, Annex) } \\
\text { Thessalonica agenda (doc. 10369/03) } \\
\text { SAA (OJ L 26, 28/01/2005) }\end{array}$ \\
\hline Macedonia & 1997 & 1997 & $\begin{array}{l}\text { Joint Declaration (29/04/1997, Annex)" } \\
\text { Thessalonica agenda (doc. 10369/03) } \\
\text { SAA (OJ L 84, 20/03/2004) }\end{array}$ \\
\hline Montenegro & 2007 & 2007 & $\begin{array}{l}\text { Council conclusions (doc. 11575/06) } \\
\text { SAA (doc. 11566/1/07) }\end{array}$ \\
\hline Bosnia & 2003 & 2003 & $\begin{array}{l}\text { Joint Declaration (OJ C 240, 07/10/2003) } \\
\text { Thessalonica agenda (doc. 10369/03) }\end{array}$ \\
\hline Ukraine & 1998 & -- & $\begin{array}{l}\text { PCA (OJ L 49, 19/02/1998) } \\
\text { ENP-AP (doc. UE-UA 1051/05) } \\
\text { Council conclusions (doc. 6420/05) }\end{array}$ \\
\hline Moldova & 1999 & -- & $\begin{array}{l}\text { PCA (OJ L 181, 24/06/1998) } \\
\text { ENP-AP (doc. UE-MD 1101/05 }\end{array}$ \\
\hline Georgia & 1999 & - & $\begin{array}{l}\text { PCA (OJ L 205, 04/08/1999) } \\
\text { ENP-AP (doc. UE-GE 4654/06) }\end{array}$ \\
\hline
\end{tabular}

The obligation de moyens provides in substance that political dialogue with the EU shall "tak[e] full advantage of diplomatic channels between the Parties, including appropriate contacts in the bilateral as well as the multilateral field, such as the United Nations, OSCE meetings and elsewhere” (PCA, generally art. 7; EU/Western Balkan states' joint declarations on political dialogue; SAA, generally art. 9). Cooperation should furthermore ensue through "providing mutual information on foreign policy decisions", or "inform[ing] and consult[ing] one another on important matters of common interest" (SAA, generally art. 9.2.). There is little cross-national variation in the legal formulas used in these texts, nor in the time of their introduction (see Table 5). Most of them were introduced in the late 1990s, as political dialogue was established. The structural constraint weighing on non-EU states' multilateral diplomacy in the OSCE is thus relatively uniform in this respect, and it cannot conclusively explain cross-national variations in non-EU states' voting behaviour.

The obligation de résultat, by contrast, is not imposed equally on all non-EU states (see Table 5). Only candidate and Western Balkan states are required to ensure an "increasing convergence of positions on international issues, and in particular on those matters likely 
to have substantial effects on one or the other party" (EU/Western Balkan states' states' joint declarations on political dialogue; SAA, generally art. 8.2.). Within the "unsteady convergence" group, the provision is binding on Albania and Serbia -but not on Turkey; within the "high convergence" group, it is binding on Croatia, Macedonia, Montenegro and Bosnia -but not on Ukraine, Moldova and Georgia. The existence of an explicit obligation de résultat thus does not suffice to explain the differential patterns of voting behaviour amongst non-EU states, although here again, such a norm does foster the likelihood of convergent behaviour.

In order to facilitate the achievement of convergence, the EU introduced in the mid 2000 an alignment mechanism (in 2003 for SAp Associates and in 2005/2006 for ENP Associates). This mechanism provides that non-EU states shall be invited by the Presidency "to align [themselves] with EU demarches, declarations and common positions on CFSP issues" (Thessaloniki agenda 2003; ENP-AP, generally point 4.1.2.). The Commission is responsible for assessing states' compliance with this obligation, and it demands, for instance, that would-be candidate states attach a justification of their nonalignment occurrences to their Answer to the Commission's Questionnaire. In praxis, the EU's alignment mechanism in the UNGA is jointly run by the NYLO and the Presidency. Whereas the former plays the role of facilitator (e.g. in organising briefings in its facilities, circulating information), the latter acts as key executive operator (e.g. by chairing meetings, communicating positions, building consensus). The alignment mechanism is usually initiated in New York, after EU member states have successfully coordinated their position internally, i.e. by reaching a consensus position on a given draft resolution. The Presidency then communicates the EU's position to the delegations of non-EU associated states, which face a "take-it or leave-it" choice. Non-EU states' delegations cannot attend to EU internal coordinating meetings, intervene in debates or formally participate in negotiations. They may only transmit the EU's invitation to align to their capital, and usually act upon instructions.

To what extent, in conclusion, can legal-institutional forces explain the Europeanisation of non-EU multilateral diplomacy in the UNGA? Probably not much. Differences in patterns of voting behaviour, it has been seen, cannot be conclusively explained by differences in institutional distance. Nor can it be explained by substantive differences in legal obligations. Comparing simultaneously the voting behaviour and the legalinstitutional settings of Ukraine, Moldova and Georgia on the one side and Armenia and Azerbaijan on the other side is very instructive. Whereas considerable differences exist in terms of voting behaviour, their institutional relationship to the EU is very similar. Besides, among those states with convergent voting behaviour, considerable differences exist in terms of institutional distance to the EU and in terms of substantive obligations. Macedonia and Moldova, for instance, over the past seventeen years, have behaved relatively similarly in the UNGA, although their institutional relation to the EU is extremely different.

\section{The underpinnings of a nascent European way of voting?}


This study partly confirms the findings by Klaus H. Goetz (2007) on "clustered Europeanisation”. It shows that Europeanisation hits most of non-EU Europe through increasing levels of voting convergence, and it suggests a method for measuring this remarkable development. But it also shows that Europeanisation does not hit non-EU Europe in a homogenous manner. Croatia and Georgia, for instance, have levels of voting alignment with EU positions that were comparable in 1993, and that tend towards voting identity today. But whereas the former has gradually adjusted to the EU's positions, changes in the latter have been more sudden. Armenia, by contrast, followed a clearly different way. Europeanisation, thus, seems to admit different pathways, rather than stages, and it therefore would be ill-advised to assume that the phenomenon has a teleological design that necessarily ends up with the equation of EU and non-EU diplomacies. The emergence, in the UNGA, of a European way of voting that transcends EU institutional borders is indeed a remarkable phenomenon, but it remains fragile, contested and possible fleeting.

Although this paper sheds some explanatory light on this remarkable development, explaining its peculiarities will require further research. So far, the following conclusions can be drawn: first, reducing institutional distances is not a prerequisite for enhancing convergence, but institutional propinquity does seem to preclude divergent voting behaviour. It is, in other words, a non-essential condition to Europeanisation. The same is true for the substantive obligations resulting from EU contractual relations with its partners: their development is not, essentially, a precondition to effective convergence, though more explicit obligations seemingly anchor convergence. The second conclusion that can be draw from these findings pertains to the role played by compliance mechanisms. In a European rule-based polity with a strong legalistic tradition, European law is logically regarded as "an important impetus for domestic change” (Panke 2007, 847). In its external relations, the EU accordingly seeks to extend its legal authority beyond its institutional borders through the establishment of conditionality regimes. These, which command mechanisms of political and legal compliance, are often viewed as key vectors of Europeanisation (Grabbe 1999). This study, however, demonstrates that in foreign policy matters, compliance plays a non-essential role in re-orientating the voting behaviour of EU partners' diplomacy. In the Western Balkans, diplomats are generally aware of the need to comply with the CFSP acquis. They know, for instance, that all instances of non-alignment with the EU will have to be justified in Brussels in their response the Questionnaire handed by the Commission prior to being granted the candidate status (interviews). But such awareness merely acts as background knowledge -it does not play a primary role in the decision to align.

Considering the findings of the paper, it is thus legitimate to infer that forces, other than legal-institutional, are at play in determining differential convergence in non-EU states' voting behaviour. First, in Moldova and Georgia, the role of emulative learning, and the significance of their sheer "desire for conformity" (Holzinger and Knill 2005), should be further researched. In those countries, foreign policy actors constantly tend to justify their alignment with EU positions through their immanent belonging to Europe. Of course, 
these representations remain subjective, as the EU has not offered any accession perspective to Black Sea states. But by voting in the UNGA with the highest possible degree of EU similarity, these Black Sea states often hope that the EU will eventually acknowledge their Europeanness and transform their subjective constructions into intersubjective beliefs, and ultimately EU accession. Second, in small-sized states (e.g. Macedonia), the contribution of simple learning should be explored. Considering the limited capacity of many Western Balkan and Black Sea diplomacies, the possibility of gaining information, expertise and guidance from EU member states' diplomatic network and aligning with EU positions certainly emerges as a rational move. It allows them to extend their foreign policy scope and make informed decisions at lesser costs. And the role of social learning should finally be examined with greatest care. Europeanisation may indeed also be driven by dispositional forces, expressed through non-EU states' redefining their national interests in collective rather than individualistic terms. In the Western Balkans, foreign policy coordination with the EU is increasingly seen as a strategic priority in its own terms. This tends to de-insulate foreign policy from the exclusive realm of national politics, and gradually fuse it with the more inclusive world of transnational politics.

\section{Acknowledgements:}

The author gratefully acknowledges comments from participants at the Jean Monnet International Conference on Human Security, organised in Kiev, Ukraine (26-29th May 2011), and also would like to thank the Research National Fund, Luxembourg for its continuous support and Ms. Natalia Sanmartín Jaramillo for her help and comments. 


\section{List of references}

Beauguitte, L. 2009. 'Multiscalar approaches of voting behaviour of European countries in the United Nations General Assembly.' In 5th ECPR General Conference. Potsdam.

Blair, A. 2004. 'Diplomacy: The Impact of the EU on its Member States.' In Contemporary European Foreign Policy, eds. Carlsnaes, W., H. Sjursen and B. White. London ; Thousand Oaks: Sage.

Börzel, T. A. 2010. 'The Transformative Power of Europe reloaded: The limits of External Europeanization.' KFG Working Paper Series(11).

Börzel, T. A. and T. Risse. 2000. 'When Europe Hits Home: Europeanization and Domestic Change.’ European Integration online Papers 4(14).

Charter of the United Nations.

Christiansen, T., et al. 2000. 'Fuzzy Politics around fuzzy borders: the European Union's 'Near Abroad'.' Cooperation and Conflict 35(4):389-415.

Falkner, G. 2000. 'Policy Networks in a Multi-Level System: Convergence Towards Moderate Diversity.' West European Politics 23(4):94-120.

Foot, R. 1979. 'The European Community's voting behaviour at the United Nations General Assembly.' Journal of Common Market Studies 17(4):350.

Goetz, K. H. 2007. 'Territory.' In Europeanization : New Research Agendas, eds. Graziano, P. and M. P. Vink. Houndmills; New York: Palgrave Macmillan.

Grabbe, H. 1999. 'A Partnership for Accession? The Implications of EU Conditionality for the Central and East European Applicants.' Robert Schuman Centre Working Paper 12.

Graziano, P. and M. P. Vink eds. 2007. Europeanization : New Research Agendas. Houndmills; New York: Palgrave Macmillan.

Hix, S., et al. 2005. 'Power to the Parties: Cohesion and Competition in the European Parliament, 1979-2001.’ British Journal of Political Sciences 35(2):209-234.

Holzinger, K. and C. Knill. 2005. 'Causes and conditions of cross-national policy convergence.’ Journal of European Public Policy 12(5):775-796.

Hosli, M. O., et al. 2010. 'Voting Cohesion in the United Nations General Assembly: The Case of the European Union.’ In 5th ECPR Pan-European Conference Porto.

Hurwitz, L. 1975. 'The EEC in the United Nations: The voting behavior of eight countries, 1948-1973.’ Journal of Common Market Studies 13:224.

Kissack, R. 2007. 'European Union Member State coordination in the United Nations system: towards a methodology for analysis.’ European Foreign Policy Unit Working Paper 2007/1.

Laatikainen, K. V. and K. E. Smith. 2006. The European Union at the United Nations: Intersecting Multilateralisms. Houndmills, Basingstoke: Palgrave Macmillian.

Lavenex, S. 2004. 'EU external governance in 'wider Europe'.' Journal of European Public Policy 11(4):680-700.

Lavenex, S., et al. 2009. 'Modes of external governance: a cross-national and crosssectoral comparison.’ In EUSA Eleventh Biennial International Conference. Los Angeles. 
Lavenex, S. and E. M. Ucarer. 2004. 'The External Dimension of Europeanization -the Case of Immigration Policies.' Cooperation and Conflict 39(4):417-443.

Luif, P. 2003. 'EU Cohesion in the UN General Assembly.' ESSI Occasional Papers(49).

Marciacq, F. 2010. 'The Europeanisation Phenomenon in Law, Party Politics and Foreign Policy -Phenomenal Research and Conceptual Refinement.' Luxembourg: University of Luxembourg.

Marciacq, F. 2011. 'Foreign policy coordination and diplomatic alignment in the OSCE: Differential patterns of Europeanisation in non EU-Europe' In 6th ECPR General Conference Reykjavik, Iceland.

Marciacq, F. 2012. 'The political geographies of Europeanisation: Mapping the contested conceptions of Europeanisation.' Journal of Contemporary European Research 7(3):in editing.

Olsen, J. P. 2007. Europe in search of political order : an institutional perspective. Oxford; New York: Oxford University Press.

Panke, D. 2007. 'The European Court of Justice as an agent of Europeanization? Restoring compliance with EU law.' Journal of European Public Policy 14(6):847866.

Peterson, M. J. 2006. The UN General Assembly. New York: Routledge.

Powers, R. J. 1980. 'United Nations Voting Alignments: A New Equilibrium.' The Western Political Quarterly 33(2):167-184.

Radaelli, C. M. 2003. 'The Europeanization of Public Policy.' In The Politics of Europeanization, eds. Featherstone, K. and C. M. Radaelli. Oxford ; New York: Oxford University Press.

Rasch, M. B. 2008. The European Union at the United Nations -The functioning and coherence of EU External Representation in a State-Centric Environment. Leiden, Boston: Martinus Nijhoff.

Sartori, G. 1970. 'Concept Misformation in Comparative Politics.' American Political Science Review LXIV(4):1033-1053.

Schimmelfennig, F. 2009. 'Europeanization beyond Europe.' Living Reviews in European Governance 4(3).

Smith, K. E. 2003. European Union foreign policy in a changing world. Cambridge, U.K.: Polity ; Malden, MA.

Stadler, K.-D. 1993. Die Europäische Gemeinschaft in den Vereinten Nationen: Die Rolle der EG im Entscheidungsprozess der UN-Hauptorgane am Beispiel der Generalversammlung. Baden Baden: Nanos.

UN Bibliographic Information System.

United Nations. 1984. 'Rules of Procedure of the United Nations General Assembly.' Voeten, E. 2008. 'United Nations General Assembly Voting Data.’ IQSS Dataverse. 